\title{
Service Encounters: \\ The Missing Link Between Service Quality Perceptions And Satisfaction
}

Srinivas Durvasula, (E-mail: srinivas.durvasula@marquette.edu), Marquette University Steven Lysonski, (E-mail: steven.lysonski@marquette.edu), Marquette University

Subhash C. Mehta, Kazakstan Institute of Management, Kazakstan

\begin{abstract}
Relationship marketing emphasizes that for a firm to be profitable, it must be attentive to those factors that affect service satisfaction. Extant research in the service sector reveals two important determinants of service satisfaction. One is service quality, and the other is the service encounter, representing the interaction between the customer and the service provider. Further, it has been demonstrated that service quality is also related to customer perceptions of the service encounter. However, a question that a remains unanswered is about the precise nature of the relationship between service quality and service encounter on one hand, and service satisfaction on the other. Is the relationship direct or indirect? Does one of the factors instead serve as a mediator? This study provides an answer by examining a sample of industrial customers in Singapore who evaluated the service dimensions of ocean freight shipping lines. Results reveal that the relationship between service quality and service satisfaction is not direct, but it is defined or mediated by customer perceptions of service encounters. Implications of the results are discussed.
\end{abstract}

\section{INTRODUCTION}

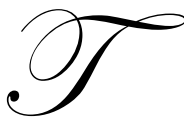

he service sector continues to eclipse manufacturing in overall growth while it becomes integral to the prosperity of the US economy. Yet, nagging complaints about service quality suggest that service firms may not be optimizing the delivery of their service. Some suggest that the declining quality may be rooted in the service encounter, the point of interaction between the customer and interfacing departments of the firm (cf. Bitner, Booms and Tetreault 1990). This interaction is central to relationship marketing since such dynamics foster satisfaction which assists in building bonds with customers. Relationship marketing argues long term profitability comes from satisfied customers who become loyal to the firm (Caruana, Pitt and Berthon 1999). Without adequate attention as to how these encounters may affect customer satisfaction, the firm may suffer suboptimal profitability. The goal of this paper is to explore these encounters by looking at the role that interfacing departments and service quality may play in customer satisfaction.

A service can be viewed somewhat like a performance (Grove, Fisk and Dorsch 1998) in that each service encounter allows the firm's personnel to perform actions and activities of value to the customer. Hence, the interpersonal dynamics that are embedded in a service encounter may have a profound impact on the satisfaction with the service despite what might seem an objective level of quality. It is likely that the departments interfacing with the client during the service encounter may have a strong bearing on the level of satisfaction. The ultimate concern becomes how satisfied the customer is with the quality of the service that is performed by departments through these encounters.

In recent years, considerable research has focused on customer satisfaction and service quality issues. In particular, this research has examined the role of service quality (and its dimensions) in the performance of a service and the impact of service encounters on customer's satisfaction with the service company. Research on British service-based firms, for example, has found empirical support linking excellence in service delivery to customer 
satisfaction, and overall business performance (Caruana, Pitt, and Morris 1995). A number of other studies also found a relationship between service quality and behavioral intentions such as repurchase, loyalty, and recommending the service providers to others. While some of these studies showed that the relationship is direct (e.g., Taylor and Baker 1994, Zeithaml, Berry and Parasuraman 1996), others found that the relationship is indirect and operates only through customer satisfaction (Anderson and Sullivan 1993; Patterson and Spreng 1997). Hence, there continues to be a gap in our understanding of how "all the pieces fit together".

Although quality and satisfaction with services are related, they are clearly distinct, yet related constructs and cannot be used interchangeably (Bitner 1990; Bitner and Hubbert 1994; Sureshchandar et al. 2002). Ziethaml and Bitner (2000) view satisfaction as a broad concept and perceived service quality as only one component of customer satisfaction. In distinguishing between the two constructs, Iacobucci, Ostrom and Grayson (1995) suggest that while service quality relates to managerial delivery of service, service satisfaction deals with customers' experience with that service. Cronin and Taylor (1992) argue that perceptions of service quality precede (is an antecedent to) customer satisfaction; customer satisfaction is then viewed as the central driving force of intentions to repeat purchase versus service quality which is viewed as having a lesser role. Caruna (2002) found that customer satisfaction does play a mediating role in the effect of service quality on service loyalty. Bitner and Hubbert (1994) have extended this stream of research to establish that customer satisfaction with service encounters, perceptions of overall service quality, and customer satisfaction are three distinct, yet highly correlated constructs. However, no study has examined how the three variables are related and the sequence in which they are causally connected. Bitner and Hubbert (1994) recommend more investigation in this area and imply that consumers' perceptions of service encounters might fundamentally affect the relationships among other service evaluation constructs (e.g., service satisfaction and service quality perceptions). How these three variables are inextricably connected continues to elude our understanding.

The purpose of this paper is to solve this puzzle and find out whether customers' perceptions of service encounters with interfacing departments mediate or define the relationship between service quality and service satisfaction. This research responds to the need to develop a clearer appreciation of the role that service encounters may play in affecting satisfaction with a service. Most importantly, though, this research contributes theoretically to our understanding of the relationships among the three service evaluation constructs and provides evidence or the missing link in the sequence of relationships that involves both antecedents and consequences of service quality. We chose to examine the connection among three constructs (service quality, service encounters and service quality) since each has been acknowledged in the literature as a vital component in a firm's success.

In this paper, we use an industrial B2B marketing setting and analyze data provided by customers on the services offered by various ocean freight shipping lines in Singapore. Since the shipping industry involves many encounters with customers by various interfacing departments, the results of the study are generalizable to other B2B industries where service encounters are also ubiquitous. The shipping industry was also selected because of its growing role in world trade and its widespread use by business organizations around the world. Singapore was seen as an ideal location for this study since it is the second largest container port in the world and a major trading and transhipment centre.

The paper proceeds as follows. First, we examine what the literature says about service encounters, service satisfaction and service quality. Next, we state the research questions and their importance. The subsequent methodology section provides the procedure and description of the sample. After reporting the results of the empirical testing, the last part provides conclusions and implications. It is important to point out that this study is exploratory in nature since it involves only one industry in a B2B context.

\section{SERVICE QUALITY, SERVICE ENCOUNTERS, AND SERVICE SATISFACTION}

\section{Service Quality}

Nearly two decades ago, researchers viewed the quest for a service quality measure as one of the most important consumer research issues (Parasuraman, Zeithaml and Berry 1985). Parasuraman, Zeithaml and Berry (1985) define service quality as the overall evaluation of a specific service determined by comparing the firm's 
performance with the customer's general expectations of how firms in that industry should perform. Perceived service quality is viewed as an overall appraisal of service (Bitner and Hubbert 1994) and as an attitude based on the customer's perception of performance (Cronin and Taylor 1992, 1994; Boulding et al. 1993). Wiele, Boselie and Hesselink (2002) and Mukherjee, Path and Pal (2003) found service quality to be strongly correlated with business performance.

Arising from the tremendous interest in service quality, researchers have developed a number of models of service quality. Among them, the model proposed by Parasuraman, Zeithaml and Berry (1985) is the most ubiquitous and most cited. These researchers established that five independent dimensions can be used to describe service quality: tangibles, reliability, responsiveness, assurance and empathy. A 22-item-scale, SERVQUAL, was developed to measure these five determinants which has been recognized as a good predictor of overall service quality (Cronin and Taylor 1992). We apply the SERVQUAL scale in this study as our metric of service quality.

\section{The Service Encounter}

The service encounter has become a major theme in the last decade concerning its role in determining customer satisfaction and its impact on service quality (Stewart 2003, Bowden and Schneider 1988). The service encounter is defined as the "dyadic interaction between a customer and service provider" (Surprenant and Solomon 1987) or more broadly as "a period of time during which a consumer directly interacts with the service" (Shostack 1985). The first definition reflects the view that a service encounter deals with role performances (Solomon et al. 1985) during which customers and service personnel act out their roles. The roles deal fundamentally with interpersonal dynamics. The later definition, however, is more encompassing since it includes not only the personnel but the physical facilities and other attributes associated with the delivery of the service. It is essential to note that Shostack's definition does not circumscribe the encounter as consisting merely of interpersonal interactions; instead, service encounters may not have any human interaction (Bitner, Booms and Tetreault 1990). Such encounters can occur between customers and various technologies such as email, web information, call centers, among others.

Danaher and Mattson (1994) propose that a more broadened view of service encounters is more realistic. In particular, they maintain that it is the collectivity of service encounters that is evaluated by the customer and not a single interaction per se. Blume (1988) also views customer service as an organisation wide effort involving people who have face to face contact with customers as well as people who serve customers indirectly. This paper uses the broadened definition articulated by Shostack and the collectivity idea a la Danaher and Mattson (1994) and Blume (1988) since we are interested in the composite of all the encounters between interfacing departments and customers.

For any service provider, interactions or encounters with customers involve a process that extends over a period to time with a variety of interfacing personnel at different locations. Zeithml and Bitner (2000) suggest that the many encounters can be likened to a cascade where there is a sequence of service encounters that customers experience. In turn, a positive evaluation of such encounters is likely to lead to greater satisfaction. Several other studies have also found that service encounter perceptions are critical to the perceived level of satisfaction in various industries (Crosby and Stephens 1987; Brown and Swartz 1989). Hence, it seems apparent that various service encounters will affect the customers' overall satisfaction and their propensity to give repeat business as addressed below.

\section{Service Satisfaction And Its Determinants}

Customer satisfaction has been widely studied in multiple areas of marketing. Convincing evidence shows that the outcomes of customer satisfaction are loyalty and repurchase intentions which, in turn, have an impact on profitability (Storbacka, Strandvik, and Gronroos 1994). Lovelock (2001) also argues that it can generate positive word of mouth, more agreeable customers, and customer retention. Hence, it is not surprising that companies spend considerable resources to assess and manage customer satisfaction.

Given that customer satisfaction is crucial to the success of any firm, the key question then is what factors determine this satisfaction? It has been suggested that the source of customer satisfaction is the value of a product or 
service (Patterson and Spreng 1997; Spreng, Dixon and Olshavsky 1993). Interestingly, an important measure of perceived value in these studies is service quality (cf. Caruana, Money, and Berthon 1998; McDougall and Lavesque 2000). Service quality per se has also been considered as an antecedent of satisfaction (Brady, Cronin, and Brand 2002; Cronin, Brady, and Hult 2000; Sivadas and Baker-Prewitt 2000). Anderson, Fornell and Lehman (1994) and Bitner, Booms, and Mohr (1994) argue that improved service quality leads to higher customer satisfaction. On the basis of these research findings, we consider service quality as one of the determinants of service satisfaction.

It has also been well documented that satisfaction is the outcome of customer's reaction to overall service encountered and the interaction with service personnel (Spreng, Dixon, and Olshavsky 1993, Crosby and Stephens 1987 ). According to Bitner (1990), customer satisfaction depends primarily on the management and monitoring of these service encounters while Booms and Nyquist (1981) contend that differentiation between service firms is based largely on the dynamics of these encounters. Along these lines, Bitner, Booms and Mohr (1994) emphasize that in service settings, customer satisfaction is often influenced by the quality of the interpersonal interaction between customer and contact employee. The overall service satisfaction then depends on how the service provider manages and monitors these service encounters (Bitner, 1990; Bolton and Drew 1992). Rust and Oliver (1994) suggest that customer satisfaction or dissatisfaction is a cognitive or affective reaction that emerges as a response to a single or prolonged set of service encounters. In a study involving a car repair facility and a health care facility, Mittal and Lassar (1996) found that the manner in which service employees relate to customers in a service encounter had a significant impact on customer satisfaction. Crosby and Stephens (1987) found that customers' encounters with their life insurance agents impacted their level of satisfaction. Experimental studies by Bitner (1990) and Suprenant and Solomon (1987) also show that the encounters have an impact on satisfaction. On the basis of these findings, we consider customer perceptions of service encounter as another determinant of service satisfaction.

\section{RESEARCH EXPECTATIONS}

Based on the preceding discussion, we expect that customer ratings of both service quality and service encounters with interfacing departments will determine overall service satisfaction. Support for this research expectation also comes from the findings of Bitner and Hubbert (1994), who have established that perceived service quality, service encounter satisfaction, and overall satisfaction are distinct, yet highly correlated. Though their study has not examined the causal ordering of the relationships, Bitner and Hubbert (1994) have suggested that service encounter experiences might alter the relationship between service quality and service satisfaction. Similarly, Peltier, Boyt, and Schibrowsky (1998) also suggested that the relationship between service quality and satisfaction is a function of multiple service encounters. Consistent with their suggestion, we expect that consumer ratings of interfacing departments mediate or define the relationship between service quality and service satisfaction. In sum, the two research expectations are as follows:

R1: Overall service satisfaction is determined by service quality and ratings of service encounters with interfacing departments.

R2: Ratings of service encounters with interfacing departments mediate the relationship between service quality and overall service satisfaction. That is, the relationship between service quality and service satisfaction is not a direct one but is filtered by service encounters.

\section{METHOD}

\section{Sample And Questionnaire Administration}

Two stages were used in this research for data collection. The first stage initially involved extensive personal interviews with shipping line executives of a major shipping line in Singapore and with shipping managers from different customers' companies. From these field work interviews, we identified important dimensions related to this study which were used to develop measures for data collection as discussed in the second stage below.

In the second stage, data were collected from shipping managers of various organizations in Singapore who regularly use the services of ocean freight companies for their exporting requirements. A sample of 220 shipping 
managers participated in the study. Their names were randomly drawn from a list of all shippers, obtained from the same large shipping company which assisted in first phase. While some of the shippers on the list represented customers of that shipping company, many were simply prospects and thus were customers of competing shipping lines. Skilled interviewers who had experience in conducting managerial interviews personally administered the survey.

The shipping managers in the sample represented a variety of firms whose primary business was manufacturing $(41.2 \%$ of the sampled firms), trading $(17.5 \%)$, or both $(26.3 \%)$. While some companies handled consumer products $(30.9 \%)$, others dealt with industrial products $(19.7 \%)$, commodities (12.6\%) or a combination of all three types (19.3\%). Across the sample, the annual turnover ranged from less than $\$ 10$ million $(49.1 \%)$ to over $\$ 100$ million (9.4\%). The annual freight expenses of these companies varied from less than $\$ 25,000$ (25.7\% of sampled firms) to over $\$ 100,000(35.4 \%)$.

\section{Measures Of Service Encounter Perceptions}

Ocean freight shipping companies often divide their organization into a number of specialized departments or support services, each of which interfaces with the customers. A preliminary investigation and interviews with managers in freight companies identified seven such departments as detailed below. These seven interfacing departments can be found in all shipping lines since they provide essential services to external customers. Administrative departments such as HRM, legal and office administration were excluded since these departments handle internal matters and do not interface with customers. The customers' perceptions of the shipping line's overall service quality and how it is differentiated from other shipping lines is determined considerably by their experiences with the support personnel of these interfacing departments.

Several scales were developed to measure customers' evaluations of the services provided by the interfacing departments of their most preferred shipping line on a 1 (worst service) to 7 (excellent service) scale. We focused on the most preferred shipping lines since the respondents were most familiar with these lines having used their services on a regular basis. Because no standardized scales exist on measuring satisfaction with interfacing departments, it was necessary to construct valid scales. Extensive interviews with senior managers and department heads of the interfacing departments were conducted to identify the specific services that each department provides to customers. From these interviews, the key service functions of each interfacing department were specified. When each scale was tested for reliability using coefficient alpha, all scales exhibited reliability values above .9. For comparison purposes, a scale is considered to be reliable if the coefficient alpha exceeds .7 (Nunnally and Bernstein 1994). The list below outlines the names of those seven departments, the number of scale items to measure the service of each department (in parentheses), and examples of scale items:

A. sales and marketing (8 items) (e.g., personalized service, product/route knowledge, help in unforeseen situations)

B. booking services (8 items) (e.g., availability of space, advice on delays, handling of sailing inquiries)

C. documentation (6 items) (e.g., speedy release of delivery orders, speedy release of bills of landing)

D. telephone services (5 items) (e.g., giving needed information, promptness in answering, courtesy/etiquette)

E. operations (7 items) (e.g., container type availability, condition of container, availability of space at warehouse)

F. personal visits(9 items) (e.g., to the shipping line office, giving needed information, prompt attention, sensitivity to customers, waiting time)

G. claims (3 items) (e.g., fairness, speedy action, simple and convenient claims procedure)

Coefficient alpha of all these scales combined was also well above 0.9, far exceeding the acceptable level of 0.7 (Nunnally and Bernstein, 1994). 


\section{Measures Of Service Quality And Service Satisfaction}

The questionnaire included SERVQUAL statements representing five service quality dimensions (i.e., tangibles, reliability, responsiveness, assurance and empathy). The scale, consisting of 22 statements adapted to the attributes of shipping lines, used scale anchors of 1 (Strongly Disagree) and 7 (Strongly Agree). Composite reliability indices of reliability, responsiveness, assurance and empathy are all well above 0.8 . The composite reliability index for the tangibles dimension is 0.69 , a value that is close to the acceptable level of 0.7 . Finally, the questionnaire included a measure of the overall evaluation (or satisfaction) of the shipping lines' services on 1 (Extremely Poor) to 7 (Excellent) Scale. The questionnaire also included background information as reported in Table 1.

\section{Analysis Method}

The purpose of this study is to determine the nature of relationship among perceptions of service quality, service encounters, and service satisfaction as well as to find out whether perceptions of service encounters mediate or define the relationship between service quality and service satisfaction. To accomplish this, we used the procedure suggested by Baron and Kenny (1986) and Holmbeck (1997). In the present example, let "A" represent perceptions of service quality, "B" represent perceptions of service encounters, and " $C$ " represent service satisfaction as shown in Figure 1. To demonstrate that perceptions of service encounter mediate or define the relationship between service quality and service satisfaction, the following conditions must be met:

A. Service quality is significantly related to service satisfaction (i.e., path A - C) and perceptions of service encounters (i.e., path A - B).

B. Service encounter perceptions are significantly related to service satisfaction (i.e., path $\mathrm{B}-\mathrm{C}$ ).

C. When paths $\mathrm{A}-\mathrm{B}$ and $\mathrm{B}-\mathrm{C}$ are controlled, a previously significant relationship between service quality and service satisfaction (i.e., path A - C) must be no longer significant.

As suggested by Holmbeck (1997), covariance structure analysis lends itself well for testing the mediated effects. Therefore, we employ this analytic procedure in this study. Figure 2 shows the basic framework used for performing the analysis.

Figure 1: Model For Mediated Effects

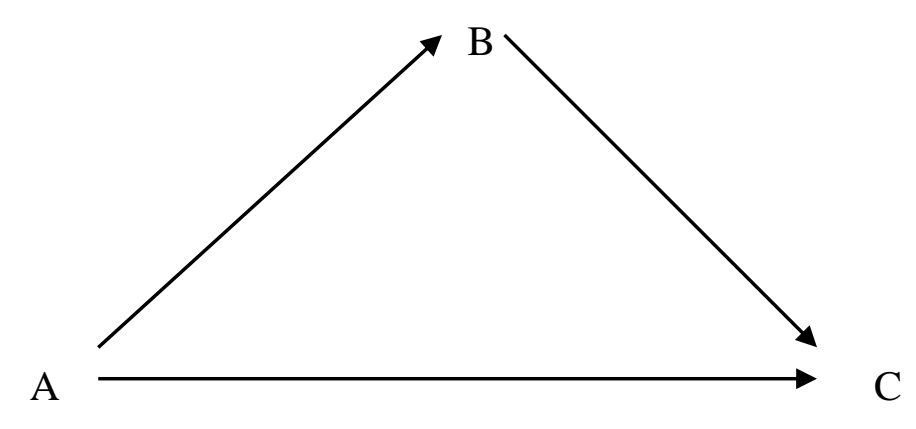




\section{Figure 2: Framework For Analyzing Mediating Effects}

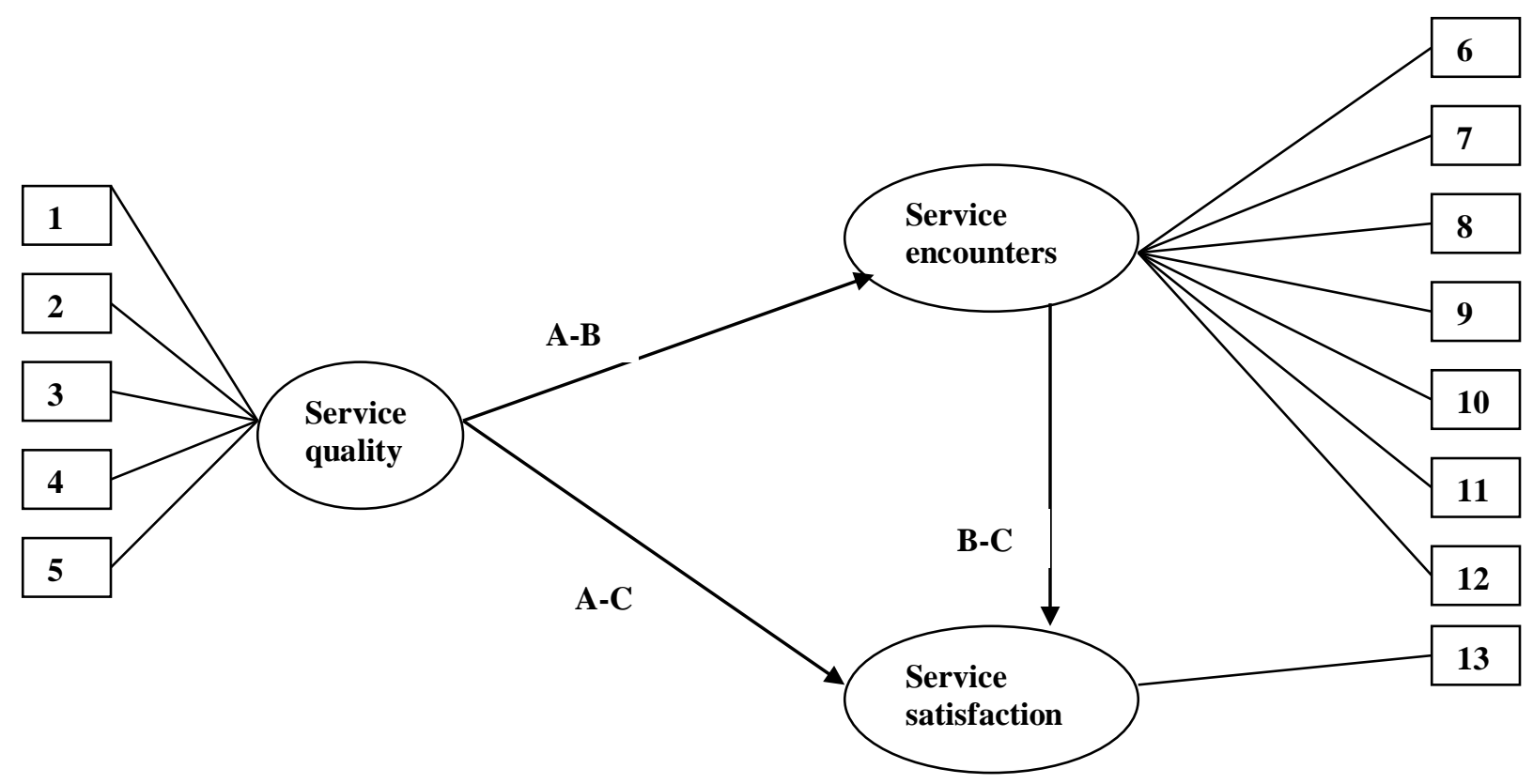

Note: As shown in the figure, the measures of service quality are: 1. Tangibles, 2. Reliability, 3. Responsiveness, 4. Assurance, and 5. Empathy. The measures of service encounter perceptions are: 6. Marketing Representatives, 7. Telephone Services, 8. Personal Visits, 9. Booking Services, 10. Documentation, 11. Operations, and 12. Claims. The measure of service satisfaction is the overall evaluation of service (i.e., 13).

\section{Results}

The five service quality dimensions (tangibles, reliability, responsiveness, assurance, and empathy) have acceptable reliability indices. Items representing individual dimensions were summed to form five composite indices representing each dimension of service quality. The seven dimensions representing service encounter perceptions (marketing representatives, telephone services, personal visits, booking services, documentation, operations, and claims) also have acceptable reliability values. Similarly, items representing individual dimensions were summed to form seven composite indices. The five service quality variables (or indices), seven service encounter perception variables, and the service satisfaction variable served as inputs; a covariance matrix was then computed. This covariance matrix was employed for performing covariance structure analysis using Lisrel 8.3.

First, we performed a series of confirmatory factor analyses. The purpose is to verify whether service quality, service encounter perceptions, and service satisfaction are really distinct or separate constructs. The various analyses revealed the following correlations: .55 between service quality and service satisfaction, .70 between service quality and service encounter perceptions, and .75 between service encounter perceptions to satisfaction. The three constructs can be considered as distinct yet correlated if the confidence intervals surrounding these correlations do not contain a value of 1 . We found this to be true after computing the confidence intervals. Other analyses also revealed that whenever a correlation between any two service constructs was constrained to one, the corresponding $\square 2$ fit was inferior to the case when the correlation was freely estimated. In sum, these results indicate that the three service constructs can indeed be treated as distinct yet correlated. We then proceeded to examine the nature of relationship among service quality, service encounter perceptions, and service satisfaction.

Table 1 shows a number of estimated models along with path estimates and fit indices. The $\square^{2}$ statistic and the associated degrees of freedom can be used to test the difference in fit of alternative models. The goodness-of-fit index (GFI), Tucker - Lewis index (TLI), and comparative fit index (CFI) are useful for assessing the adequacy of fit 
of individual models (cf. Gerbing and Anderson 1993). Both TLI and RNI provide unbiased estimates of corresponding population parameters, and their mean values over repeated sampling are not affected by sample size.

We now explain the results using Figure 2 and Table 1. In Model 1, only the relationship between service quality and service satisfaction (i.e., path A-C) is examined. This path is statistically significant, given that the t-value of 8.68 far exceeds the t-value of 2 at $95 \%$ confidence level. The size of the path coefficient of .55 is also large, indicating a strong relationship between service quality and service satisfaction. The various fit indices (e.g., GFI, CFI, and TLI), with values above .8, indicate moderate fit for the model.

The results of other models can be similarly interpreted. For example, results of model 2 indicate that service quality is significantly related to perceptions of service encounters (path A-B). This relationship is also strong, judging from the size (i.e., .57) of the coefficient. Model 3 shows that perceptions of service encounters have a strong and significant relationship with service satisfaction (path B-C). The size of various fit indices (all are above .8) again indicates moderate fit. Based on Models 1 to 3, we can say that both service quality and service encounter perceptions are individually related to service satisfaction (paths A-C and B-C). Hence, there is support for the first research expectation (R1). Also, service quality is related to service encounter perceptions (path A-B).

Table 1: Covariance Structure Analysis Of Service Quality Perceptions

\begin{tabular}{|c|c|c|c|c|c|c|}
\hline Fit / Path est. & Model 1 & Model 2 & Model 3 & Model 4 & Model 5 & Model 6 \\
\hline$\square^{2} / \mathbf{d f}$ & $512.78 / 65$ & $458.08 / 65$ & $422.8 / 65$ & $375.5 / 64$ & $291.44 / 64$ & $291 / 63$ \\
\hline GFI & .80 & .81 & .81 & .81 & .82 & .85 \\
\hline TLI & .80 & .82 & .84 & .86 & .90 & .90 \\
\hline CFI & .83 & .85 & .87 & .88 & .92 & .92 \\
\hline $\begin{array}{l}\text { SQ -> SE } \\
\text { (i.e., A - B) }\end{array}$ & ----- & .57 (9.94) & ----- & $.58(10.07)$ & $.57(10.07)$ & $.57(10.02)$ \\
\hline $\begin{array}{l}\text { SE -> SAT } \\
\text { (i.e., B - C) }\end{array}$ & ----- & ----- & $.93(12.63)$ & ----- & $.93(12.63)$ & $.88(9.16)$ \\
\hline $\begin{array}{l}\text { SQ -> SAT } \\
\text { (i.e., A - C) }\end{array}$ & $.55(8.68)$ & ----- & $\begin{array}{l}---- \\
\end{array}$ & $.57(9.13)$ & ----- & $.06(0.67)$ \\
\hline
\end{tabular}

Note:

1. "A" represents service quality, "B" represents service encounter perceptions, and "C" represents service satisfaction.

2. The table shows fit statistics and path estimates, with t-values shown in parentheses. For example, for Model 1, the parameter estimate for the service quality - service satisfaction path (i.e., A - C) is .55. This estimate is significant, given a t-value of 8.68 . 3. We also computed other fit indices such as RNI and Delta2. Across the various models, these fit indices are identical to CFI.

The key question now is the type of role played by service encounter perceptions in these relationships. In particular, do service encounters mediate the relationship between service quality and service satisfaction? This question can be answered by looking at the results of Models 4 to 6 . Model 4 shows that in the absence of path B-C, service quality is related to both service encounters and service satisfaction (i.e., paths A-C and B-C). However, as Model 6 results indicate, when the relationship between service encounter perceptions and service satisfaction (i.e., path A-B) is also included, the previously significant relationship between service quality and service satisfaction (i.e., path A-C in model 4) now turns out to be non-significant (estimate of path A-C in Model $6=.05$, t-value $=.67$ ). Further, the fit of Model 6, when all three paths are estimated, is no different from the fit of Model 5, where path A-C, representing the direct relationship between service quality and service satisfaction is constrained to zero. This finding can be verified by looking at the identical fit indices such as GFI, TLI, and CFI for Models 5 and 6 . Moreover, the $\chi^{2}$ difference in fit between the two models of 0.44 (1 df.) is also not significant (p-value > .05). Based on the tests for mediating affects (cf. Baron and Kenny 1986 and Holmbeck (1997), all of these results clearly establish that the relationship between service quality and service satisfaction is mediated by perceptions of service encounters. Hence, there is support for the second research expectation (R2). 


\section{CONCLUSION AND IMPLICATIONS}

The results clearly confirm previous research in that service satisfaction is affected by both service encounter perceptions and service quality perceptions. With respect to the research expectations which under gird this study, satisfaction with service quality is indeed mediated by service encounters. Because of the intangibility of a service, customers may derive their perceptions by more than just the outcomes when a service is delivered. Instead, the relationship customers have with interfacing departments during encounters seems to intercede between perceptions of quality and ultimate satisfaction.

Discussion will now focus on strategic implications in five main areas:

- $\quad$ Impact of service encounters

- $\quad$ Service profit chain considerations

- $\quad$ Use of an internal marketing audit

- $\quad$ Relationship marketing building

- Use of the critical incident technique

The findings add a compelling perspective on the impact of service encounters in that such encounters seem to have more power in shaping satisfaction than just service quality. The most plausible explanation deals with the role of service providers in cultivating relationships with the customer as they deliver the service. Although the service might seem objective (i.e., getting specific goods shipped from one point to another in a timely, efficient and effective manner), the personnel of the service provider may have a critical impact on the feelings or emotions of the customer. Service personnel that are helpful, knowledgeable and agreeable will make the service encounter more enjoyable or fulfilling for the customer versus rude and impatient personnel. Improper behavior by personnel may compel the customer to seek out a new shipper even if the goods are shipped successfully.

The philosophy behind the service profit chain maintains that internal marketing (i.e., satisfaction of personnel in the firm) is vital to the profitability of a firm (Heskett et al. 1994). Satisfied personnel are more likely to be cheerful when serving customers and, hence more cooperative unlike disgruntled employees who may act out their frustration on customers. Because there is a positive link between employee satisfaction and customers' evaluation of the service provider (Anantharaman 2002), it is crucial that service firms value and satisfy their personnel. In the rubric of the service profit chain, unhappy service personnel can become "terrorists" rather than "apostles" in the way they interact with customers. Lovelock (2001) notes that effective service encounters by employees is a combination of skills and the correct employee disposition. Hence, firms must be circumspect in the way they recruit, train, compensate and motivate interfacing department personnel so that these workers are attentive to the satisfaction of the customer.

A common practice in some firms is to use a marketing audit to gauge the extent to which the firm is responsive to customer needs and uses modern marketing practices. Traditionally the audit focuses more on external marketing and not on internal marketing considerations. An internal marketing audit should focus on the interfacing departments and their level of satisfaction and tools available to them to perform their functions. This audit would also measure the degree to which interfacing departments feel empowered to do their job effectively and the obstacles they confront in dealing with customers. Geralis and Terziovski (2003) found that empowerment practices improve productivity, performance and service quality.

The findings also have enormous implications for relationship marketing. Relationship marketing is concerned with maintaining long term relationships with customers rather than engaging in single transactions. Since it is much cheaper to keep an existing customer rather than recruit a new one, means should be taken so that interface departments are all focused on this goal. Zeithml and Bitner (2000) point out that sales incentives in organizations are set up in such a way to reward generating new customers and not retaining existing ones. Perhaps, interfacing departments need to be given incentives to keep current customers satisfied so that they become loyal customers 
Bitner, Booms and Tetreault (1990) recommend the use of critical incident technique (CIT) to identify the sources of satisfaction and dissatisfaction in service encounters. This approach could be used by each interfacing department so as to understand the role that each department may be playing in enhancing or hurting satisfaction. Such a method permits identifying specific occurrences and behaviors that underlie dissatisfaction or satisfaction with encounters with various interfacing departments. Such knowledge then can be used for developing programs to monitor customer satisfaction, training interface personnel or creating guidelines or procedures to execute optimal service. Bitner, Booms and Tetreault (1990) also recommend that the CIT can be used to identify situations when employees need more empowerment rather than rules and to define the action alternatives that personnel can employ.

In sum, the findings of this study should be of interest to shipping lines and to other firms operating in similar B2B environments. These firms should realize that both contact persons as well as support personnel of various interfacing departments are critical to the service performance. Focusing on service quality alone without appreciating how it is delivered by interfacing departments is misguided according to the implications of our findings. In the end, failure to appreciate the critical role that interfacing departments play in customer satisfaction may mean that shipping lines and other B2B firms are setting the stage for lower customer retention and ultimately lower profits.

\section{REFERENCES}

1. Anantharaman, C.R.N. (2002), The Relationship Between Management's Perception of Total Quality Service and Customer Perceptions of Service Quality, Total Quality management, 13 (1), 69-88.

2. Anderson, E.W., C. Fornell and D.R. Lehmann. (1994), Customer Satisfaction, Market Share and Profitability: Findings from Sweden, Journal of Marketing, 58, 3, 53-66.

3. Baron, R.M. and D.A. Kenny. (1986), The Moderator - Mediator Variable Distinction in Social Psychological Research: Conceptual, Strategic, and Statistical Considerations, Journal of Personality and Social Psychology, 51 (6), 1173-1182.

4. Bitner, M.J. (1990), Evaluating Service Encounters: The Effects of Surroundings and Employee Responses, Journal of Marketing, 54, April, 69-82.

5. Bitner, M.J., B.H. Booms, and L.A. Mohr. (1994), Critical Service Encounters: The Employees Viewpoint, Journal of Marketing, 58, 4, 95-106.

6. Bitner, M.J., B.H. Booms, and M. S. Tetreault. (1990), The Service Encounter: Diagnosing Favorable and Unfavorable Incidents, Journal of Marketing, 54, January, 71-84.

7. Bitner, M. and A. Hubbert. (1994), Encounter Satisfaction Versus Overall Satisfaction Versus Quality in Service Quality: New Directions in Theory and Practice, R. Rust and R. Oliver (Eds.), CA:Sage Publications, $72-94$.

8. Blume, E. R. (1988), Customer Service: Giving Customers the Competitive Edge, Training and Development Journal, 42, September, 24-31.

9. Bolton, R. N. and J. H. Drew. (1992), Mitigating the Effect of Service Encounters, Marketing Letters, 3, 1, 57-70.

10. Booms, B. H. and J. L. Nyquist. (1981), Analyzing the Customer/Firm Communication Component of the Service Marketing Mix in J. Donnelly and W. George (Eds.), Marketing of Services, American Marketing Association, Chicago, IL:171-7.

11. Bowden, D.E. and B. Schneider. (1988), Services Marketing and Management: Implications for Organizational Behavior in Staw, B. M. and Cummings, L. L. (Eds.), Research in Organizational Behavior, 10, JAI Press, Greenwich:CT, 43-80.

12. Boulding, W., A. Kalra, R. Staelin, and V. Zeithaml. (1993), A Dynamic Process Model of Service Quality: From Expectations to Behavioral Intensions, Journal of Marketing Research, February, 30, 7-27.

13. Brady, M.K., J.J. Cronin, and R.R. Brand. (2002), Performance-Only Measurement of Service Quality: A Replication and Extension, Journal of Business Research, 55 (January), 17-31.

14. Brown, S. W. and T. Swartz. (1989), A Gap Analysis of Professional Service Quality, Journal of Marketing, 53, April, 92-8.

15. Caruana, A. (2002), Service Loyalty: The Effects of Service Quality and the Mediating Role of Customer Satisfaction, European Journal of Marketing, 38, 7/8, 811-955. 
16. Caruana, A., A.H. Money, and P.R. Berthon. (1998), Service Quality and Satisfaction - The Moderating Role of Value, European Journal of Marketing, 34 (11/12), 1338-1352.

17. Caruana A., L. Pitt, and P. Berthon. (1999), Excellence-Market Orientation Link: Some Consequence for Service Firms, Journal of Business Research, January, 5-15.

18. Caruana, A., L. Pitt, and M. Morris. (1995), Are There Excellent Service Firms, and Do They Perform Well?, The Service Industries Journal, 15, 3, 243-56.

19. Cronin, Jr., J..J., M.K. Brady, and G.T.M. Hult. (2000), Assessing the Effects of Quality, Value, and Customer Satisfaction on Consumer Behavioral Intentions in Service Environments, Journal of Retailing, 76 (2), 193-217.

20. Cronin, J. J. and S.A. Taylor. (1994), SERVPERF versus SERVQUAL: Reconciling Performance Based and Perceptions-minus-expectations measurement of Service Quality, Journal of Marketing, January, 58, 135-31.

21. Cronin, J.J. and S.A. Taylor. (1992), Measuring Service Quality: A Reexamination and Extension, Journal of Marketing, July, 56, 55-68.

22. Crosby, L. and N. Stephens. (1987), Effects of Relationship Marketing on Satisfaction, Retention and Prices in the Life Insurance Industry, Journal of Marketing Research, 24, November, 404-11.

23. Geralis, M. and M. Terziovski. (2003), A Quantitative Analysis of the Relationship Between Empowerment Practices and Service Quality Outcomes, Total Quality Management and Business Excellence, 14, 1, 45-59.

24. Gerbing, D.W. and J.C. Anderson. (1993), Monte Carlo Evaluation of Goodness-of-Fit Indices, in Testing Structural Equation Models, Kenneth A. Bollen and J. Scott Long (Eds.)., Newbury Park:CA.

25. Grove, S., R. Fisk and M. Dorsch. (1998), Assessing the Theatrical Components of the Service Encounter: A Cluster Analysis Examination, Service Industries Journal, 18,3, 116-134.

26. Hallowell, R. (1996), The Relationships of Customer Satisfaction, Customer Loyalty, and Profitability: An Empirical Study, International Journal of Service Industry Management, 7 (4), 27-42.

27. Heskett, J., T. Jones, G. Loveman, W. E. Sasser, and L. Schlesinger. (1994), Putting the Service-Profit Chain to Work, Harvard Business Review, March-April, 164-174.

28. Holmbeck, G.N. (1997), Toward Terminological, Conceptual, and Statistical Clarity in the Study of Mediators: Examples from the Child-Clinical and Pediatric Psychology Literatures, Journal of Consulting and Clinical Psychology, 65 (4), 599-610.

29. Iacobucci, D., A. Ostrom, and K. Grayson. (1995), Distinguishing Service Quality and Customer Satisfaction: The Voice of the Consumer, Journal of Consumer Psychology, 4 (3), 277-303.

30. Lovelock, C. (2001), Services Marketing ( $4^{\text {th }}$ ed.), New Jersey:Prentice Hall.

31. McDougall, G.H.G. and T. Levesque. (2000), Customer Satisfaction with Services: Putting Perceived Value into the Equation, Journal of Services Marketing, 14 (5), 392-410.

32. Mittal, B. and W. M. Lassar. (1996), The Role of Personalization in Service Encounters, Journal of Retailing, 72, 1, 95-109.

33. Mukherjee, A., P. Path, and M. Pal. (2003), Resource, Service Quality and Performance Triad: A Framework of Measuring Efficiency in Banking Services, The Journal of the Operational Research Society, 54, 7, 723-738.

34. Nunnally, J. C. and I. Bernstein. (1994), Psychometric Theory, New York:McGraw-Hill.

35. Parasuraman, A., V.A. Zeithaml, and L.L. Berry. (1985), A Conceptual Model of Service Quality and Its Implications for Future Research, Journal of Marketing, 49, Fall, 41-50.

36. Patterson, P.G. and R.A. Spreng. (1997), Modeling the Relationship between Perceived Value, Satisfaction and Repurchase Intentions in a Business-to-Business Service Context: An Empirical Examination, International Journal of Service Industry Management, 8 (5), 414-434.

37. Peltier, J.W., T. Boyt, and J.A. Schibrowsky. (1998), Relationship Building, Marketing Health Services, 18 (3), 16-24.

38. Rust, R.T. and R.L. Oliver. (1994), Service Quality: Insights and Managerial Implications from the Frontier. Service Quality: New Dimensions in Theory and Practice, Thousand Oaks, CA:Sage Publications, 1-19.

39. Sivadas, E. and J. Baker-Prewitt. (2000), An Examination of the Relationship between Service Quality, Customer Satisfaction and Store Loyalty, International Journal of Retail and Distribution Management, 28 (2), pgs.46- 61. 
40. Shostack, G. L. (1985), Planning the Service Encounter in J. Czepiel, M. Solomon, and C. Suprenant (Eds.), The Service Encounter: Managing Employee/Customer Interaction in Service Businesses, Lexington, MA: Lexington, 243-254.

41. Sivadas, E. and J.L. Baker-Prewitt. (2000), An Examination of the Relationship between Service Quality, Customer Satisfaction and Store Loyalty, International Journal of Retail \& Distribution Management, 28 (2), 73-82.

42. Solomon, M., C. Suprenant, J. Czpiel, and E. Gutman. (1985), A Role Theory Perspective on Dyadic Interactions: The Service Encounter, Journal of Marketing, 49, winter, 99-111.

43. Spreng, R.A., A. L. Dixon, and R. W. Olshavsky. (1993), The Impact of Perceived Value on Consumer Satisfaction, Journal of Consumer Satisfaction, Dissatisfaction, and Complaining Behavior, 6, 50-55.

44. Stewart, D. (2003), Piecing Together Service Quality: A Framework for Robust Service, Production and Operations Management, 12, 2, 246- 265.

45. Storbacka, K., T. Strandvik, and C. Gronroos. (1994), Managing Customer Relationships for Profit: The Dynamics of Relationship Quality, International Journal of Service Industry Management, 5 (5), 21-38.

46. Suprenant, C. and M. Solomon. (1987), Predictability and Personalization in the Service Encounter, Journal of Marketing, 51, 86-96.

47. Sureshchandar, G., R. Chandrasekharan, and R. Anantharaman. (2002), The Relationship Between Service Quality and Customer Satisfaction-A Factor Specific Approach, The Journal of Services Marketing, 16, 4, 363-379.

48. Taylor, S.A. and T.L. Baker. (1994), An Assessment of the Relationship Between Service Quality and Customer Satisfaction in the Formation of Consumers' Purchase Intentions, Journal of Retailing, 70 (2):162178.

49. Weile, T., P. Boselie, and M. Hesselink. (2002), Empirical Evidence for the Relationship Between Satisfaction and Business Performance, Managing Service Quality, 12, 3, 184-200.

50. Zeithaml, V.A, L.L. Berry, and A. Parasuraman. (1996), The Behavioural Consequences of Service Quality, Journal of Marketing, Vol. 60 (April 1996), pp 31-46.

51. Zeithaml, V. A. and M. J. Bittner. (2000), Services Marketing, Boston:Irwin and McGraw-Hill. 